\title{
The Triassic eucynodont Candelariodon barberenai revisited and the early diversity of stem prozostrodontians
}

Agustín G. Martinelli, Marina Bento Soares, Téo Veiga De Oliveira, Pablo G. Rodrigues, and Cesar L. Schultz

Acta Palaeontologica Polonica 62 (3), 2017: 527-542 doi:https://doi.org/10.4202/app.00344.2017

The dental anatomy of Candelariodon barberenai from the Dinodontosaurus

Assemblage Zone (Pinheiros-Chiniquá Sequence, Santa Maria Supersequence, late

Ladinian-early Carnian) of south Brazil, is redescribed. Candelariodon was

originally classified as Eucynodontia incertae sedis and our analysis recovered this taxon

deeply nested within Probainognathia, as the sister taxon of Potheriodon plus

Prozostrodontia. The lower postcanine dentition of Candelariodon has several apomorphies

shared with Prozostrodon, Santacruzgnathus, Brasilodon/Brasilitherium, and some basal

mammaliaforms (Morganucodon, Megazostrodon), such as a lingual cingulum with

discrete cusps e and $\mathrm{g}$ and two distinct morphologies in the tooth row. The

reinterpretation of Candelariodon as a probainognatian cynodont more derived than Probainognathus and the rich Brazilian fossil record document an important adaptive radiation of non-mammaliaform prozostrodontians and closely related forms prior to the origin of the mammaliaform clade.

Key words: Cynodontia, Probainognathia, Prozostrodontia, Dinodontosaurus Assemblage Zone, South America, Brazil.

Agustín G. Martinelli [agustin martinelli@yahoo.com.ar], Marina Bento Soares [marina.soares@ufrgs.br], Pablo G. Rodrigues [pablogr@bol.com.br], and Cesar L. Schultz [cesar.schultz@ufrgs.br], Laboratório de Paleontologia de Vertebrados, Departamento de Paleontologia e Estratigrafia, Instituto de Geociências, Universidade Federal do Rio Grande do Sul (UFRGS), Av. Bento Gonçalves 9500, Agronomia, 91540-000, Porto Alegre, RS, Brazil. Téo Veiga de Oliveira [teovoli@yahoo.com.br], Divisão de Mamíferos do Museu de Zoologia da UEFS, Departamento de Ciências Biológicas, Universidade Estadual de Feira de Santana (UEFS), Av. Transnordestina s/n, Bairro Novo Horizonte, 44036-900, Feira de Santana, BA, Brazil. 
This is an open-access article distributed under the terms of the Creative Commons

Attribution License (for details please see creativecommons.org), which permits unrestricted use, distribution, and reproduction in any medium, provided the original author and source are credited.

For Full text $(927.9 \mathrm{kB})$ 